\title{
"TRÊS POEMAS"
}

- LUBI PRATES

\author{
é nas minhas costas \\ que eu guardo a história \\ do antes \& do depois. \\ uma memória preservada \\ para além de artifícios tecnológicos \\ no código genético \\ que me determinou determinará \\ negra. \\ é nas minhas costas \\ que eu guardo a história \\ do antes silenciado \\ do depois traçado no agora. \\ é nas minhas costas \\ que eu guardo a história \\ do antes: o encurvamento \\ os açoites destruindo o silêncio \\ é nas minhas costas \\ que o rasgo abre sangra cicatriza, \\ mas permanece. \\ é nas minhas costas \\ que eu guardo a história \\ do depois: este ousar erguer-se, \\ um edifício que se constrói \\ a partir dos escombros.
}


perdi seu corpo negro

na cidade

durante aquela primavera que tivemos em 2013.

perdi seu corpo negro

na cidade

porque sequer nos alcançamos: corremos em direções opostas quando a polícia chegou.

perdi seu corpo negro

na cidade

e só descobri

pelos noticiários

sobre seu corpo negro

atingido por balas de borracha

sobre seu corpo negro

detido, porque tinha na mochila

uma garrafa de desinfetante

sobre seu corpo negro

sempre no limite entre

a vida e a morte.

perdi seu corpo negro

na cidade

e seu corpo negro

poderia ser meu corpo

negro. 
minha cidade tem uma ferida

aberta, um rastro

onde corre um rio

sujo

eu tenho uma ferida

aberta, um rasgo

onde corre sangue

sujo

e por décadas procurei

sinais cosmopolitas de nascença

este:

agora

a poça de sangue aos

meus pés

escorre

do meu rasgo para

a ferida aberta desta

terra e

se eu me deito sobre esta cidade

imediatamente

ela tem o meu tamanho

falamos do que é sujo.

LUBI PRATES (1986, São Paulo, Brasil) - poeta, editora e tradutora. Tem dois livros publicados, coração na boca (2012) e triz (2016), além de diversas participações em antologias nacionais e internacionais. Seu terceiro livro, um corpo negro, foi contemplado pelo PROAC com bolsa de criação e publicação de poesia e será lançado em 2018. É sócia-fundadora e editora da nosotros, editorial e é editora da revista literária Parênteses. Dedica-se a ações que combatem a invisibilidade de negros e mulheres no meio literário. 